\title{
The Impact of Initial Public Offerings on Firms' Performance: Disentangling Treatment from Self- Selection Effects
}

\author{
Dario Salerno ${ }^{1}$
}

\begin{abstract}
Using a unique sample of privately held and firms that went public on the European and Asian Stock Exchanges between 2007 and 2011, we investigate the IPO's impact on the firms' performance after correcting for endogenous selection and by disentangling equity issues effects from other effects. We find that companies that are going public are more profitable than their matched private firms, while they experience a decrease in profitability over the post-IPO period. These results are resilient to different empirical strategies that address selection bias. Second, after disentangling equity issues effects from other effects, we observe a continuous decline in firms' profitability in each individual year following the IPO year.
\end{abstract}

JEL classification numbers: G10, G30, G32, L25.

Keywords: IPOs, Private firms, Profitability, Selection bias.

1 University of Naples "Parthenope".

Article Info: Received: February 25, 2021. Revised: March 16, 2021.

Published online: April 15, 2021. 


\section{Introduction}

Do going public companies experience a change in their performances over the post-IPO period than similar private firms? Stated differently, is the well-known IPOs long-run underperformance phenomenon due to the transition to public equity markets, or simply to the fact that firms plan their IPOs to coincide with periods of a strong set of results that they are aware cannot continue in the future? Finally, if there is a causal relation between going public and IPO performance, is it simply attributable to the equity issues that typically occurs during an IPO or also to the effects deriving to the status of "public company"?

These questions have considerable relevance as numerous successful companies across the world decide at a certain stage of their life to go public. Furthermore, despite the accumulation of empirical evidence, the inability to properly address endogeneity concerns leave these important issues unresolved. From a theoretical side, there are several arguments supporting the idea that the decision to go public yields various advantages for a firm. Specifically, going public allows them to raise additional financial resources (e.g., Jain and Kini, 1994; Teoh, et al., 1998; Chemmanur, et al., 2010), to diversify company's wealth (e.g., Pagano, et al., 1998; Bernstein, 2015), to increase the liquidity of firm's securities which in turn should reduce the cost of equity financing (Bhide, 1993; Chemmanur, et al., 2010; Asker, et al., 2016; Acharya, and $\mathrm{Xu}, 2017$ ) and to increase their reputation which should lead to an increase of a firm sales and profit margin (Forestieri, 2015). Nevertheless, there are at least two theoretical reasons for expecting that a going public firm may get worse performance than those would have been experienced it was remained private. The first reason is related to the agency problems associated with the transition to public equity markets that may undermine firm incentives to invest in innovation and encourage actions that are not in the long-term best interest of the firm (Berle and Means, 1932; Jensen and Meckling, 1976), such as aggressive dividend policy (DeAngelo and DeAngelo, 1990). The second reason relates to detailed disclosure requirements for public firms and the cost of regulation that can hinder profitability (Pagano and Röell, 1998). Conclusively, given the contrasting predictions, whether IPO firms experience a variation in their performance after the going public decision is an empirical puzzle that corporate finance literature has seek to solve. An early example is Jain and Kini (1994) who find that operating performance of U.S. firms declines subsequent to the IPO. Following the Jain and Kini (1994) pivotal paper, a large body of literature has tested the IPO long-run underperformance hypothesis using various firm-level indicators, such as productivity, innovation, amount of investments and the risk of financial distress (among others: Pagano, et al., 1998; Lee and Wahal, 2004; Chemmanur, et al., 2010; Bernestein, 2015; Megginson et al., 2016). Overall, these studies suggest that the IPO long-run underperformance is a robust phenomenon that extends across equity markets in several countries and time periods. Our empirical study fills a gap in the literature because, to our knowledge, previous studies have mainly analysed the change in performance of the IPOs without running a counterfactual analysis. This 
approach does not allow disentangling the impact of the IPO due to the inherent selection bias associated with the decision of going public. Indeed, if firms decide to go public in periods of unusually good performance levels, as argued by Jain and Kini (1994), then post-IPO performance may mix life cycle effects with the IPO effect. To our knowledge, there are few studies that estimate the IPO effects on the firm outcome while controlling for the endogenous nature of the decision to go public. Bernestein (2015) deals with endogeneity concerns by using a control sample of innovative firms that file an initial registration statement with the Securities and Exchange Commission (SEC) in an attempt to go public, and then either complete or withdraw their filing. Acharya et al. (2017) adopt several econometric models accounting for selection bias by using a large panel data set of private and public firms built from Standard \& Poor's (S\&P) Capital IQ. However, these studies investigate the impact of going public process on firms' innovation and focuses on U.S. firms.

Thus, as far as can be ascertained, we are the first to examine the IPO's impact on the firms' profitability after correcting for endogenous selection issues. To do this, we analyse a unique dataset consisting of 1,758 firms, of which 879 firms went public on the European and Asian Stock Exchanges between 2007 and 2011 and 879 firms remain private over the same period. Specifically, private firms have been selected through a matching technique (namely, the propensity score approach: Rosenbaum and Rubin, 1983) from a list of more than 180,000 firms. The choice to focus on the European and Asian IPO markets depends mainly on two reasons. First, this choice takes into account that they are highly representative of the worldwide IPO market. Accordingly, in the period 2007-2011 European and Asian's IPO market produced 2,704 IPOs, whilst only 968 IPOs were produced in the U.S. IPO market (Zephyr Bureau Van Dijk). Second, there is a lack of data on the U.S. privately held firms necessary for a direct analysis of the choice between public and private firms (Asker, et al., 2016). Thus, by focusing on the European and Asian IPO markets we can collect accounting data on private firms that able us to select through sample matching techniques (i.e. the propensity score approach) a valid control group (Saunders and Steffen, 2011). This aspect is crucial to overrun the self-selection bias associated with the decision to go public of which, to the best of our knowledge, suffer previous studies.

We find that companies that are going public are more profitable than their counterparts, while they experience a decrease in profitability over the post-IPO period. These results are resilient to different techniques (i.e., OLS estimations by resorting to the Wald tests, difference-in-differences approach, treatment effect model and the propensity score matching combined with the difference-indifferences) used to evaluate the impact of IPOs net to self-selection effect and the level of profitability recorded by the firm at the IPO time. We also find that the decrease in profitability does not strictly depend on dilutive effects related to the issue of new shares during the IPO.

The rest of the paper is organized as follows. We review prior literature in Section 2. In Section 3, we describe the data, sample, and firms' performance measures. In 
Section 4, we implement the empirical analyses. We conclude in Section 5.

\section{Literature Review}

IPOs are among the most important decision made by private firms. This decision is theoretically affected by many different factors and it is very difficult to capture all of them in a single model. This has given rise to a large body of empirical research that has focused on different aspects of IPO, by using different firm-level variables related to productivity, innovation, amount of investments and the risk of financial distress (e.g., Pagano, et al., 1998; Lee and Wahal, 2004; Chemmanur, et al., 2010; Megginson et al., 2016; Huynh et al., 2018). Nevertheless, there is a small empirical literature contrasting listed and unlisted firms. This is mainly due to the lack of data on privately held firms necessary for a direct analysis of the choice between going public and remaining private (Asker, et al., 2016). In particular, the available empirical literature on the decision to go public was initially focused on the ex-ante characteristics and ex-post effects of the investment policy (Pagano et al., 1998; Ljungqvist, and Wilhelm, Jr., 2001; Brav, 2009; Saunders and Steffen, 2011; Mortal, and Reisel, 2013), but more recently has devoted to investigate the role of innovation both for public and private firms (Bernstein, 2015; Acharya, and $\mathrm{Xu}, 2017)$.

Recently, there are emerging literature contrasting public and private firms. Brav (2009) investigate differences in capital structure decisions between public and private firms. Michaely and Roberts (2012) show that listed firms pay relatively higher dividends than unlisted. Bernstein (2015) shows that IPO firms are more likely to acquire external innovation than firms that withdraw their IPO. Using a large dataset of private firms, Asker et al. (2016) show that public firms are less responsive to changes in their investment opportunities than private firms. Acharya and $\mathrm{Xu}$ (2017), documents the innovation and firms' dependence on external capital, comparing public and private firms.

Our study is related to two main strands of literature that can explain the impact as to how going public decision can affect the firm's performance. It is closely related to a large literature that studies the determinants of IPO (among others: Pagano et al., 1998; Ljungqvist, and Wilhelm, Jr., 2001; Brav, 2009) and is also related to a body literature that studies the impact of IPO on firm's performance (among others: Jain and Kini, 1994; Mikkelson, et al., 1997; Chemmanur, et al., 2010).

\subsection{Determinants of going public decision}

There is a long debate in the financial economics surrounding the potential determinants of IPO (Pagano et al., 1998; Ljungqvist and Wilhelm, 2001; Bancel and Mittoo, 2009; Mortal, and Reisel, 2013). A number of empirical studies investigated the aspects of IPO decisions, not only from firms' ex-ante characteristics but also from the ex-post consequences (financial and policies) of such a decision (Pagano, et al., 1998; Bancel and Mittoo, 2009).

Overall, literature emphasizes that the going public decision depends on several 
factors. First, a company go public to raise external funds to finance firm's growth (Pagano, et al, 1998; Brav, 2009; Acharya and Xu, 2017) instead of increasing leverage or placing private equity to obtain external funding. In this respect, previous theories (e.g., Holmström and Tirole, 1993; Gennaioli, et al. 2014) have highlighted the benefits of raising external equity to obtain low cost direct financing without the intervention of banks or private-equity investors. For instance, Holmström and Tirole (1993) highlight that raising external equity offers the opportunity to obtain low cost direct financing without the intervention of banks or private equity investors. Second, the creation of a public market in which the shareholders can convert some of their wealth into cash (Stoughton and Zechner, 1998; Chemmanur and Fulghieri, 1999). Indeed, IPO affects the liquidity of a firm's shares as well as the possibility for diversification by the initial shareholders of the firms. Thus, the greater the stake in the equity portion by the initial holders, the greater will be their incentive to diversify (Pagano et al., 1998). Several theoretical studies have suggested the importance of the diversification reason for firms that go public (Rydqvist and Hoghölm, 1995; Stoughton and Zechner, 1998; Chemmanur and Fulghieri, 1999). As pointed out by Rydqvist and Hoghölm (1995) the diversification is a reason for IPOs firms to liquidate their owners' investment rather than to finance growth. Third, go public gives the possibility to create liquidity in the stock and makes share trading cheaper than informally searching for a counterpart (Booth and Chua, 1996; Bolton and Von Thadden, 1998). Indeed, the liquidity of a firm's shares is a function of its trade volume. More specifically, firms that have a certain size may benefit from such liquidity gains. Hence, larger firms are more likely to attempt an IPO. To go public can imply a conflict of interest between the controlling shareholder and the minority shareholders, as is exposed the market's assessment of managerial decisions. This conflict takes a specific form when the controlling shareholders manipulate the corporate earnings to their advantage (Chen et al., 2013; Lo et al., 2014). In this respect, managers could inflate earnings in order to present favorable performance and increase the offer price. According to Chen et al. (2013), some managers in firms with high informationuncertainty surrounding IPOs engage in earnings management for opportunistic purposes. Fourth, according to the windows of opportunity theory (Rajan and Servaes, 1997), more firms tend to go public in hot issue markets period (Ritter, 1984). In this respect, companies recognizing the timing of going public decision to take advantage of temporarily favorable market conditions and attractive stock prices (companies recognizing that other companies in their same industry are overvalued have an incentive to go public) (Ritter, 1991). For instance, Pagano et al. (1998) show that the industry market to book value is the main factor affecting the going public decision in Italy. They find a significant positive association between the median industry market to book value and the probability of an IPO.

Although the theories mentioned above show that going public decision may bring benefits to firms and its shareholders, another body of literature analyzes the costs of going public. In sum, there are at least three theoretical factors that induce firms to remain private. First, according to the adverse selection theories, issuers can be 
assumed to know more than investors about the true value of a firm. This increases the degree of information asymmetry that may adversely affect the quality of the companies going public (Leland and Pyle, 1977). As argued by Chemmanur and Fulghieri (1999) adverse selection costs affect young and small firms, inasmuch they have lower visibility and little track records than large companies. However, it is also consistent with Pagano et al., 1988 who finds that younger and smaller Italian firms are less likely to go public. Second, the disclosure rules of stock exchanges force firms to reveal important information about Research \& Development (R\&D) intensity and future marketing plans to competitors in the going public process. This loss of confidentiality could discourage firms from going public (Campbell, 1979; Maksimovic and Pichler, 2001). Third, going public process implicate considerable direct costs, such as underwriting costs, and indirect costs, such as increased disclosure of accounting information, stock exchange fees and public scrutiny. These administrative expenses and fees are fixed and therefore could create a disincentive for smaller companies to go public (Yosha, 1995; Pagano and Röell, 1998).

\subsection{The IPO impact on firm's performance}

Empirical research on the link between going-public decision and long-run performance has a long history. Since early studies (e.g, Ritter, 1991; Loughran and Ritter, 1995) have documented on a drastic decline in performance in the post-IPO period, the phenomenon has been extensively studied and remains intriguing. Indeed, literature has continued to evolve on both the theoretical and the empirical side by investigating the relationship between going public and firm's performance, in terms of innovation (e.g., Bernstein, 2015; Acharya and Xu 2017), investment (e.g., Pagano et al. 1998, Asker, et al., 2016, Gilje and Taillard 2016), profitability (e.g., Jain and Kini, 1994; Pástor, et al., 2009), and product market performance (e.g., Chemmanur, et al., 2010).

In particular, these studies present three main views on the impact of IPOs in the lung-run.

One view focuses on the likely increase in agency costs when a company becomes public (Jensen and Meckling, 1976; Kim et al., 2004; Latham and Braun, 2010). An early paper by Jensen and Meckling (1976) document that a reduction in management ownership that typically occur when a firm goes public is likely to lead to the agency problem. This is due to the growing conflict of interests between initial owners and shareholders and as the managers have an incentive to increase perquisite consumption, company performance may be affected .

A second view focuses on the theoretical assumption in which managers attempt to window-dress accounting numbers before going public (Teoh et al., 1988; Stein, 1989; Alhadab, Clacher, and Keaset al., 2016; Kouwenberg and Thontirawong, 2016). This implies an initial overestimation in the pre-listing period, with a decrease in performance in the ex-post IPO period .

A third view for the decline in operating performance is due to the fact that 
entrepreneurs time coincide with unusually good performance periods, which they know cannot be sustained in the future (Ritter, 1984; Helwege and Liang, 2004). In sum, the theories rely on the post-IPO decline in operating performance refer to the presence of information asymmetries and the conflict of interests between initial entrepreneurs and new shareholders. This would imply that IPO firms have negative performances compared to private firms in the years following the listing.

Despite so different views that document the long run underperformance hypothesis, there is no general consensus about these negative returns (Ritter and Welch, 2002; Brav, 2009). As discussed by Ritter and Welch (2002), the long-term performance of IPOs is very sensitive to the choice of econometric methodology and to the choice of sample period. Thus, at the minimum, there is a need to apply different econometric techniques to fully overcome the endogeneity issues that relate the going-public decision. Our empirical analysis of the impact of IPO on firms' performance is based on a counterfactual analysis and this allow us to disentangle the effect of treatment from the long-run impact.

\section{Data}

To reply to our research questions, we build a unique dataset including accounting and financial data on European and Asian IPOs and privately held firms for 20062015 . Creating this dataset involves a multistep-process and the use of various databases.

First, we obtain the list of European and Asian IPO firms that went public from 1 January 2007 to 31 December 2011 from Zephyr Bureau Van Dijk (BVD) database. The sample period starts in 2006 because we need information about firms' characteristics before the IPO year and stops in 2011 as we estimate the impact of IPO over the four post-IPO years. Following previous studies (e.g., Mazzola and Marchisio, 2002; Anderson and Reeb, 2003; Martinez, et al., 2007), we exclude financial firms, such as banks, insurance companies, and pension funds, inasmuch are not directly comparable to industrial and other service firms. This yields an initial sample of 1.820 IPOs. Then, we match IPO firms on Thomson Reuters Eikon database using the ISIN code, to extract accounting data for going public companies. In doing so, we excluded companies for which we do not find accounting information even only for a fiscal year between the pre-IPO year and the four postIPO years. As this sample selection criterion is very strict, it yields a reduced sample of 879 IPOs. Table 2 presents sample distribution by country and region. Asian IPO firms account for about $54.7 \%$ of the sample, while the other $45.3 \%$ of the sample is distributed across all European countries.

Second, we obtain European and Asian privately held firms' financial statements information from Orbis Bureau Van Dijk (BVD) database. Specifically, we get a list of non-financial private firms, which are incorporated in Europe or Asia. From this initial list, we exclude firms for which we do not find accounting information even only for a fiscal year between the 2006 and 2015. Thus, we obtain a final list of 182.611 privately held firms. A potential concern regarding the use of this group 
of firms as a control sample is that the going public decision is not random but influenced by various factors, like firm-specific characteristics. In addition, the stock exchange companies admit firms to the official list just if they meet the stock exchange's listing requirements. As a result, IPO firms can be significantly different from private firms and these divergences, rather than the going public decision, may be responsible for any differences in post-IPO operating performance.

\subsection{Matched sample and propensity score approach}

As mentioned above, in selecting matching firms for IPOs, we are aware that going public is a choice that a firm faces at some point in its life cycle and that this decision is not casual.

To mitigate this endogeneity concern, we adopt a matching technique based on propensity scores developed by Rosenbaum and Rubin (1983). The same approach has been used by other studies, such as Saunders and Steffen (2011), Brav et al. (2018), to deal with the self-selection issue.

The characteristic of this matching technique consists in controlling for a large set of observable characteristics, but like all matching procedures, it does not control the unobservable factors.

In our context, the propensity score takes into account a set of independent variables that could drive the decision of a firm to go public. Specifically, the first step of this matching procedure consists in the implementation of a logit model for the endogenous choice variable (IPO $=1$ for IPO firms, 0 , otherwise) with a vector of $\mathrm{X}$ variables.

Then, in the second step, the predicted probability from the logit model is used as the propensity score and each IPO firm is matched with the unlisted firm with the closest propensity score. Thus, the final sample is composed of 879 IPO companies matched with 879 private firms.

In particular, based on previous literature, in the logit model we control for the following variables that could influence the going-public decision. First, we consider the natural logarithm of the total asset (TA), the natural logarithm of the firms' age (Age), and a set of industry dummies. This is because, as argued by Chemmanur and Fulghieri (1999), IPOs take place in an environment where insiders have private information about firm value, but outsiders can produce this information by incurring costs. Thus, in presence of information asymmetry, smaller and younger firms, and those operating in industries characterized by higher information production costs are more likely to remain private. Second, as additional determining factor we use the growth sales (Growth), because, as pointed out by as pointed out by Jain and Kini (1994), firms choose to go public in periods of unusually good performance levels. Third, we take into account in our matching model the volatility of the stock market indexed (Volatility). This is because, as highlighted by Pastor and Veronesi (2009), entrepreneurs have a real option to take their firms public and choose to exercise this option when stock market conditions are more favourable. Finally, consistent with Lewellyn (2014), we include in our 
matching model a set of country dummy variables, because of the decision of a firm to go public may also be geographically driven. Fig. 1 shows a successful matching procedure, by suggesting that the balancing property condition is fulfilled, i.e., the propensity scores for IPO and private firms do not differ significantly. Thus, the differences between the control sample and the sample exposed to treatment is clearly eliminated.

\subsection{Profitability indicators}

In order to estimate the impact of going public decision on the profitability, we employ several accounting-based indicators widely used by previous literature (e.g., Francis et al., 2016; Schepens, 2016).

Our first profitability indicator is the return on assets (ROA), which is estimated as the ratio between net income on total assets. Alternatively, we measure the profitability through the ratio of the earnings before interest and taxes on total assets (ROA2).

\subsection{Descriptive statistics and univariate tests: IPO firms and matched control firms}

Table 3 presents descriptive statistics related to firm-specific variables and firms' performance variables for going public companies and matched control firms in the pre-IPO year. Furthermore, for each variable of interest, we perform t-tests and ztest on the difference-in-mean and median between the group of IPO firms and the matched control group. It is worthwhile to note that despite the use of the propensity score approach, some differences between the two groups of firms remain. Indeed, we find that IPO firms in the pre-listing year are in average more mature (11 years vs 9 years), smaller (about 24 million of euros vs approximately 44 million of euros), less leveraged (58.8\% vs 67.3\%), and show a higher growth (17\% vs $13 \%$ ) compared to control firms. Furthermore, IPO firms exhibit higher profitability. For example, we find that IPO firms show in median a ROA of $6.4 \%$ compared to a value of $3.6 \%$ for matched control firms that is significant at the 1 percent level.

Table 4 shows univariate tests relative to median (mean) values and median (mean) changes of the indices measuring profitability from the IPO calendar year to four years later. According to previous studies (e.g., Jain and Kini, 1994; Pagano et al., 1998), we find a significant decline in profitability in the post-IPO years. For example, while IPO firms exhibit a median ROA of $6,4 \%$ in the pre-IPO year, they show an average ROA of $3.0 \%$ in the fourth post-IPO year. Interestingly, this negative change in profitability indicators is significant also compared to the change in the performance of matched control firms. Indeed, in the same period, the matched control sample experience an increase of the median ROA from $3.6 \%$ to $3.8 \%$. 


\section{Empirical analysis}

\subsection{Going public and firm's performance: disentangling self-selection and treatment effects}

In this section we try to understand if going public companies experience a change in their performances over the post-IPO period and, if so, to what extent it is attributable to the transition to public equity markets (treatment effect), or to the fact that firms plan their IPOs to coincide with periods of a strong set of results (selfselection effect). In doing so, we are aware that the characteristics exhibited by the firms at the IPO time, including the level of performance they experienced before the going public, may influence the post-IPO performance. In addition, we recognize that because the use of propensity score matching has just mitigated the differences between IPO firms and matched-control firms, we have to make an additional effort for disentangling treatment effects from self-selection effects.

Thus, in order to properly evaluate the relationship between going public and firm performance, we first estimate OLS regressions where a firm's profitability (ROA and $R O A 2$ ) is a function of two dummies - one that equals 1 for IPO firm in the preIPO year $\left(\boldsymbol{I P O} \boldsymbol{O}^{\text {pre }}\right)$ and 0 otherwise, the other one (IPO$\left.{ }^{\text {post }}\right)$ that equals 1 for IPO firms during the four years after the IPO - and various other firm-specific characteristics, macroeconomic variables, and industry and state dummies. In Table 1 , we report a detailed description of the variables we use in our analyses while the OLS estimation (Eq. 1) is the following:

$$
\begin{aligned}
& \text { Perf }=\alpha+\zeta_{i}+\gamma_{p r e} I P O^{\text {pre }}+\gamma_{\text {post }} I P O^{\text {post }}+\beta_{1} T A+\beta_{2} \text { Age }+ \\
& \sum \beta_{i} \text { Year }+\sum \beta_{j} \text { State }+\sum \beta_{k} \text { Industry }+\varepsilon_{i, t}
\end{aligned}
$$

where, $\boldsymbol{P e r f}$ represents firms' profitability; $\zeta_{\boldsymbol{i}}$ represents year-fixed effects; $T A$ is the natural logarithm of the total asset; Age is the natural logarithm of the firms age; Year denotes the year of IPO; State denotes the head-quarters countries of firms; Industry denotes the sector of firms, and $\boldsymbol{\varepsilon}$ is the random error term.

Results are reported in Table 5. First, we find that the coefficient of IPO $\boldsymbol{O}^{\text {pre }}$ is positively and significantly related (at the 5\% confidence level or less) to profitability measures. In terms of economic significance, the regression analysis indicates that, before the IPO, going public firms exhibit in average a higher profitability ( $+0.998 \%$ in terms of $R O A$ and $+2.56 \%$ in terms of $R O A 2)$ than those of matching firms. Overall, these results seem to confirm the hypothesis that firms time their IPOs to coincide with years of high financial performance. This condition, in fact, helps going public firms to pass the screening from the stock exchange company and allows them to obtain a high evaluation by the IPO market participants. Second, we find that the IPO ${ }^{\text {post }}$ dummy is negative and significant (at the $1 \%$ confidence level or less) related to both profitability variables. In terms of economic significance, we find that the transition to public markets reduces $R O A$ and $R O A 2$ 
of $0.842 \%$ and $0.619 \%$ respectively. This evidence is consistent with the previous literature which supports the long-run underperformance hypothesis (Jain and Kini 1994; Pagano, et al., 1998; Chemmanur, et al., 2010).

However, the analysis of the statistical and economic significance of the coefficients exhibited by the $\boldsymbol{I P \boldsymbol { O } ^ { \text { post } }}$ dummy is per se not sufficient to conclude that IPO firms under-perform matched firms in terms of profitability because of the going public decision. Indeed, in order to properly evaluate the effect provided by IPO net of the self-selection effect, we have to resort to the following Wald test (Eq. 2):

$$
\gamma_{\text {post }}-\gamma_{\text {pre }}>0
$$

The results are reported in the last rows of Table 5 and point out that profitability is significantly lower in IPO firms during the four post-IPO years also to the net of self-selection effect.

Hence, our findings seem to indicate that while controlling for differences in preIPO performance between IPO firms and matched firms, the former show a decline in profitability. However, one concern with this analysis is that it does not properly control for unobservable that could drive both post-IPO performance and the decisions to go public. In the next section, we try to delve more deeply on the endogenous nature of the decision to go public by performing additional econometric analyses.

\subsubsection{Robustness}

As above discussed, the estimation reported in Table 5 may be biased by unobservable factors that could affect both a firm's performance and its decision to go public. To further ease this concern, we use several identification strategies enabled by our large panel data set of private and public firms.

The first approach adopted is the treatment effect model, which correct for selection bias by using the inverse Mills ratio. Specifically, the treatment effect model includes two equations. In the first step, a probit model (Eq. 3) is estimated to determine the decision to go public (the dummy variable IPO indicating the treatment condition).

$$
I P O=\left\{\begin{array}{l}
1 \text { if } I P O^{*}>0 \\
0 \text { if } I P O^{*} \leq 0
\end{array}=I P O^{*} \pi+\delta Z+v\right.
$$

The estimated parameters are used to calculate the inverse Mills' ratio, which is then included as an additional explanatory variable to adjust for the selection bias in the following OLS estimation (Eq. 4):

$$
\begin{aligned}
& \text { Perf }=\alpha+\beta_{1} I P O+\beta_{2} T A+\beta_{3} \text { Age }+\sum \beta_{i} \text { Year }+\sum \beta_{j} \text { State }+ \\
& \sum \beta_{k} \text { Industry }+\beta_{4} \text { Mills }+\varepsilon_{i, t}
\end{aligned}
$$


Table 6 panel A reports the first-step estimation of the treatment effect model. The coefficient on stocks traded (stock_turnover) is positive and significant, indicating that when the turnover ratio of domestic shares on the exchanges is high, firms are more likely to go public. This is consistent with the IPO hot market theory by Ritter (1984). The positive and significant coefficient on current ratio indicates a higher probability of going public for firms that are capable to comply with short-term and long-term debt. Domestic credit provided by the financial sector in the percentage of GDP and firms' size (measured by total assets) affect the probability for firms to go public. The second step-estimation results which are reported in panel B of Table 6. The fact that the Inverse Mills ratio's coefficient is statistically significant in all regressions, provides evidence of sample selection bias in the one-stage estimates of IPO firm effects. In particular, the negative coefficient on the inverse Mills ratio indicates that the covariance between the error terms in the selection and outcome equations is negative. This negative sign implies that the unobserved factors that encourage the firm's decision to go public on the stock exchange are negatively correlated with firms' profitability. Interestingly, the coefficients of the $\boldsymbol{I P O}^{\text {post }}$ dummy still remain negative and significant to the ROA.

To further control about the non-randomness of public and private firms, we implement the propensity score matching combined with the DID approach that compares firms transitioning from private to public with those remain private (e.g., Blundell and Dias, 2000; Acharya et al, 2017).

Before a formal analysis, we provide a graphical snapshot of the profitability in the treatment and control groups ${ }^{2}$. Fig.1 depicts the density estimates for distributions of the Roa and Roa2 covariates for European and Asian sample after the propensity score matching application in year T (IPOs' year). As these figures show, the differences between the performance of the control sample and the sample exposed to treatment are clearly mitigated ${ }^{3}$. This result complements the parallel trend assumption, which states that the outcome for the treatment and control group follows the same time trend, in absence of treatment.

Then, we turn to test the pattern described above more formally in a DID specification. To estimate the treatment effect, we compare the changes in the outcome variables of the treatment group (before and after the implementation of the treatment) with those of the control group. According to the model of Blundell and Dias (2000), we combine propensity score matching with the DID approach ${ }^{4}$. After achieving the closely matched treatment and control groups, we apply the DID

\footnotetext{
${ }^{2}$ In particular, we consider one year before the treatment period and four years after the treatment period.

${ }^{3}$ It is useful to note that the differences between the performance of the IPO and private Asian companies (despite the reduced control sample) are almost completely eliminated. In addition, this allows us to better construct the abnormal performance variables which are explained in section 4.4.

${ }^{4}$ To investigate the impact, we require firms to have at least four consecutive years of data and one year before for both IPO and private firms. We use the year that an IPO firm goes public as the fictitious IPO year for its matched private. Thus, we consider the group exposed to treatment the IPO firms four years after the listing for its matched private firm.
} 
approach to difference out the cross-sectional heterogeneity or common time trend that affects both groups of firms. Table 7 presents the results from the DID analysis for firms in the period before and after treatment. We compute the Diff-in-Diff estimator as the difference of changes in the profitability of the treatment and control groups around the IPO. In the period after the treatment, firms that transition from private to public suffers a drop for the profitability $(-2.6 \%$ in terms of ROA and $-3.8 \%$ in terms of ROA2). The DID for the treatment and the control groups is statistically significant at $1 \%$. To the extent that the performance of the private firms represents the counterfactual scenario if the IPO firms did not go public, the results provide strong evidence that going public involves a decline in profitability, probably due to the increase in agency.

Further, we provide DID specification to have a clearer scenario on differences in trends between treated and control firms before and after the IPO dates and then compare the difference across the two groups. In particular, the specification that is estimated in Table 8, is:

$$
\begin{aligned}
& \text { Perf }=\alpha+\zeta_{i}+\mu_{i}+\beta_{1} \text { Time }+\beta_{2} \text { Treated }+\beta_{3} D I D+\beta_{4} T A+ \\
& \beta_{5} \text { Age }+\sum \beta_{i} \text { Year }+\sum \beta_{j} \text { State }+\sum \beta_{k} \text { Industry }+\varepsilon_{i, t}
\end{aligned}
$$

where Time is an indicator variable that takes a value one for all the years after the event date and zero otherwise and $\mathrm{T}$ is an indicator variable that takes a value one for firms in the treatment group and zero for targets in the control group. All the regressions are estimated with time $\left(\boldsymbol{\zeta}_{\boldsymbol{i}}\right)$ and firms $\left(\boldsymbol{\mu}_{\boldsymbol{i}}\right)$ fixed effects ${ }^{5}$.

We also use fixed effects panel data models to control for unobserved heterogeneity and find the results to be similar. The results, shown in Rows 1-4 of Table 8, for the coefficient $D I D$ is similar in both specifications and confirms that the treated group suffers a drop for the profitability compared to the pre-treatment period. As shown in Table 10, the effect is significant at $1 \%$ in all specification by showing that the treatment has a negative effect for profitability (e.g., $R O A$ decreases by about 1,6\%). Overall, the evidence provided by robustness tests confirms the results discussed in the previous section and indicate that while controlling for observed and unobserved differences in the pre-IPO year between IPO firms and matched firms, the former experience a decline in profitability.

However, this analysis, which is in itself interesting, raises the need to understand which factors drive the variation in IPO firms' performance. Stated differently, are these changes simply due to the stock capital increase that typically occurs in the course of an IPO or also to the effects derived from "being a public company"? Indeed, as discussed in Sections 1 and 2, previous studies identify many reasons for which IPOs can be detrimental to firms' performance. Thus, in the next Section, we

\footnotetext{
5 We cluster standard errors at firm level in addition to employing firm fixed effects to account for possible serial correlation around the IPO event.
} 
describe additional analyses performed to delve more deeply on this issue and disentangling effects deriving from the equity issues (which is a "one-time" effect) from other IPO effects (which are "financial and non-financial permanent" effects).

\subsection{Going public and firm's performance: disentangling equity issues (one- time) effects from other (permanent) effects}

As above illustrated, one potential limitation of the results analyzed in the previous section is that we cannot establish if they can be simply attributed to the equity issues that typically occurs during an IPO or also to the effects deriving to the status of "public company".

In this respect, the infusion of new equity issue may have a dilutive effect on firm's profitability indicators (e.g., Mikkelson et al., 1997), especially in the short-term. Thus, to shed new light on the relationship between going public and firm post-IPO performance, we perform an additional analysis by dividing the period in the prelisting year, IPO's year and post-IPO years. More in details, we use the following regression framework:

$$
\begin{aligned}
& \text { Perf }=\alpha+\zeta_{i}+\gamma_{p r e} I P O^{\text {pre }}+\gamma_{i n} I P O^{i n}+\gamma_{p o s t} I P O^{\text {post }}+\beta_{1} T A+ \\
& \beta_{2} \text { Age }+\sum \beta_{i} \text { Year }+\sum \beta_{j} \text { State }+\sum \beta_{k} \text { Industry }+\varepsilon_{i, t}
\end{aligned}
$$

where $\boldsymbol{I P \boldsymbol { O } ^ { \text { in } }}$ is a dummy variable which is set to one for IPO's year and 0 otherwise. To test the effect of IPO on firm's performance also a net to equity issues effect, we perform the following Wald test (Eq. 7-8):

$$
\begin{aligned}
& \gamma_{\text {pre }}-\gamma_{\text {in }}>0 \\
& \gamma_{\text {in }}-\gamma_{\text {post }}>0
\end{aligned}
$$

The results are reported in Table 9. It is worth to note that the coefficient of the IPO ${ }^{\text {pre }}$ variable remains positive and significant (at the 5\% confidence level or less) related to firms' profitability. In addition, we find that the coefficient of dummy IPO's year $\left(\boldsymbol{I P \boldsymbol { O } ^ { \text { in } }}\right)$ is positively $(0.0139)$ and significant $(\mathrm{t}=2.98)$ related to the $R O A 2$, while the coefficient of dummy $\boldsymbol{I P O}^{\text {post }}$ is negatively and significant (at $5 \%$ level of confidence or less) related to profitability. Interestingly, the results of Wald tests, which are reported in the last rows of Table 9, confirm that firm profitability declines with the IPO regardless of the equity issues' dilution effects. However, we suspect that the negative effects of IPO become more pronounced over the post-IPO years when a firm after the rebalancing of its financial structure begins. To stress this argument, we decide to run the following regression over a post-IPO estimation period: 


$$
\begin{aligned}
& \text { Perf }=\alpha+\zeta_{i}+\gamma_{\text {pre }} I P O^{\text {pre }}+\gamma_{i n} I P O^{i n}+\gamma_{\text {post } 4} I P O^{\text {post } 1}+ \\
& \gamma_{\text {post }} I P O^{\text {post } 2}+\gamma_{\text {post } 4} I P O^{\text {post } 3}+\gamma_{\text {post } 4} I P O^{\text {post }}+\beta_{1} T A+\beta_{2} A g e+ \\
& \sum \beta_{i} \text { Year }+\sum \beta_{j} \text { State }+\sum \beta_{k} \text { Industry }+\varepsilon_{i, t}
\end{aligned}
$$

where $I P \boldsymbol{O}^{\text {post1 }}$ is a dummy variable which is set to one for the first year after the IPO and 0 otherwise; IPO ${ }^{\text {post } 2}$ is a dummy variable which is set to one for the second year after the IPO and 0 otherwise; IPO ${ }^{\text {post } 3}$ is a dummy variable which is set to one for the third year after the IPO and 0 otherwise; IPO $\boldsymbol{P o s t 4}^{\text {is a }}$ dummy variable which is set to one for the fourth year after the IPO and 0 otherwise.

Once again, the impact of the IPO in the listing year and in the years after the going public can be tested by using the Wald test, as follows:

$$
\begin{aligned}
& \gamma_{\text {pre }}-\gamma_{\text {in }}>0 \\
& \gamma_{\text {in }}-\gamma_{\text {post1 }}>0 \\
& \gamma_{\text {in }}-\gamma_{\text {post } 2}>0 \\
& \gamma_{\text {in }}-\gamma_{\text {post } 3}>0 \\
& \gamma_{\text {in }}-\boldsymbol{\gamma}_{\text {post }}>0
\end{aligned}
$$

The results, which are reported in Table 10, confirm that there is a continuous decline in firms' profitability in each individual year following the going public. It is worthwhile to note the moving from the dummy IPO ${ }^{\text {post } 1}$ to the dummy IPO $^{\text {post4 }}$, the magnitude of the coefficients as well as their significance increases for all the dependent variables. For example, looking at the findings reported in column 1, the coefficient of the dummy $\boldsymbol{I P O}^{\text {post } 1}$ is $-0.0121(\mathrm{t}=-2.83)$ while that the dummy $\boldsymbol{I P O}^{\text {post } 1}$ is -0.000944 , but not statistically significant.

Furthermore, the Wald tests show that, in the second, third and fourth year this change in profitability is highly significant. For example, the difference between the coefficient of the dummy the dummy $\boldsymbol{I P O ^ { \text { post } }}$ and that of the dummy IPO $\boldsymbol{O}^{\text {post } 1}$ is significant at $1 \%$ level of confidence. Thus, we can conclude that the post-IPO decline in firms' profitability is a phenomenon that is more exacerbated in the longterm.

\section{Conclusion}

In this study, we used a unique and representative sample of European and Asian firms to examine two related questions regarding the going-public decisions of private firms. In the first part of the paper, we investigated an important aspect of IPOs - i.e. the impact on firm profitability - by disentangling self-selection and treatment effects. In the second part of the paper, we investigated the relationship between going public and firms' performance by disentangling equity issues (one- 
time) effects from other (permanent) effects. Our results were as follows. First, we find that companies that are going public are more profitable than their matched private firms, while they experience a decrease in profitability over the post-IPO period. We estimate propensity score approach to mitigate selection bias related to the choice of going public, the treatment effect model to control for unobserved factors, and we exploit a DID combined with propensity score and DID specification to gauge the treatment effect. Second, after disentangling equity issues effects from other effects, we find that there is a continuous decline in firms' profitability in each individual year following the IPO year.

All the above results are robust to controlling for the interactions between various performance measures and firm-specific variables.

We are confident that the findings of this paper are of special interest for many subjects, first of all firms' stakeholders. Indeed, it is unquestionable that the attraction of going public for a firm's CEO and its main shareholders can be very strong. The IPO represents a unique opportunity they have to gain great visibility and reputation, capitalize on the hard work done for their firm, and raise a large amount of cash for business investments. However, the results of our studies suggest that the lure of going public can be like the siren song. Accordingly, while several among very successful companies in Europe and Asia, like the Italian Yoox, probably would not be what they actually are if they had not joined public market, many other firms have experienced the potential shortcomings of an IPO.

We believe that also regulators and policymakers that in many areas of the world, like in the European Union, are concerned to adopt more proportionate rules to support SME listing (e.g., European Commission, 2018), should pay close attention to our results to better direct their regulatory action. 


\section{Labels of figures and tables}

Table 1: Description of variables.

\begin{tabular}{|c|c|c|}
\hline Variables & Symbol & Description \\
\hline \multicolumn{3}{|r|}{ Dependent variables } \\
\hline Operating performance 1 & $R O A$ & The net income divided by total assets. \\
\hline Operating performance 2 & ROA2 & The EBIT divided by total assets. \\
\hline $\begin{array}{l}\text { Independent variables } \\
\text { IPO }\end{array}$ & $I P O$ & $\begin{array}{l}\text { Dummy variable which is set to } 1 \text { if the firm has launched an } \\
\text { IPO and } 0 \text { otherwise. }\end{array}$ \\
\hline IPO-pre & $I P O^{\text {pre }}$ & $\begin{array}{l}\text { Dummy variable which is set to } 1 \text { for one year pre IPO year } \\
\text { and } 0 \text { otherwise. }\end{array}$ \\
\hline IPO-in & $I P O^{\text {in }}$ & $\begin{array}{l}\text { Dummy variable which is set to } 1 \text { for IPO's year and } 0 \\
\text { otherwise. }\end{array}$ \\
\hline IPO-post & $I P O^{\text {post }}$ & $\begin{array}{l}\text { Dummy variable which is set to } 1 \text { for four years post IPO year } \\
\text { and } 0 \text { otherwise. }\end{array}$ \\
\hline IPO-post1 & $I P O^{p o s t 1}$ & $\begin{array}{l}\text { Dummy variable which is set to } 1 \text { for the first year after the } \\
\text { IPO and } 0 \text { otherwise. }\end{array}$ \\
\hline IPO-post2 & $I P O^{\text {post } 2}$ & $\begin{array}{l}\text { Dummy variable which is set to } 1 \text { for the second year after the } \\
\text { IPO and } 0 \text { otherwise. }\end{array}$ \\
\hline IPO-post3 & $I P O^{\text {post3 }}$ & $\begin{array}{l}\text { Dummy variable which is set to } 1 \text { for the third year after the } \\
\text { IPO and } 0 \text { otherwise. }\end{array}$ \\
\hline IPO-post4 & $I P O^{\text {post }}$ & $\begin{array}{l}\text { Dummy variable which is set to } 1 \text { for the fourth year after the } \\
\text { IPO and } 0 \text { otherwise. }\end{array}$ \\
\hline Region & dummy_region & $\begin{array}{l}\text { Dummy variable which is set to } 1 \text { if the region is Europe and } 0 \\
\text { if the region is Asia. }\end{array}$ \\
\hline Size & $T A$ & Natural logarithm of the total asset. \\
\hline $\begin{array}{l}\text { Age } \\
\text { Industry }\end{array}$ & $\begin{array}{l}\text { Age } \\
\text { Industry }\end{array}$ & $\begin{array}{l}\text { Natural logarithm of the firm age. } \\
\text { Dummy variables each equal to } 1 \text { if the firm operates in the } \\
\text { corresponding sector and zero otherwise. }\end{array}$ \\
\hline Capital ratio & e_ta & The book value of total equity divided by total assets. \\
\hline $\begin{array}{l}\text { Market Capitalization } \\
(\% \text { GDP })\end{array}$ & mark_cap_gdp_ & $\begin{array}{l}\text { Market capitalization of listed domestic companies in } \\
\text { percentage of GDP. }\end{array}$ \\
\hline Return of market index & rend_mkt_avg & The average of return of domestic market index. \\
\hline Current ratio & ca_cl & The current assets divided by current liabilities. \\
\hline Listed & n_listed_ & Total of listed domestic companies. \\
\hline Stocks traded & stock_turnover_ & Stocks traded, turnover ratio of domestic shares (\%). \\
\hline Leverage & debt_ratio & Total liabilities divided by total assets. \\
\hline $\begin{array}{l}\text { GDP growth } \\
\text { Sales Growth }\end{array}$ & $\begin{array}{l}\text { GDP } \\
\text { Growth }\end{array}$ & $\begin{array}{l}\text { The countries GDP growth rate between two consecutive years. } \\
\text { The firm's sales growth rate over the previous one year. }\end{array}$ \\
\hline Financial deepening & credit_gdp & Domestic credit provided by financial sector (\% of GDP). \\
\hline
\end{tabular}


Table 2: Sample composition for IPO firms and the control group.

\begin{tabular}{|c|c|c|c|c|}
\hline & \multicolumn{2}{|c|}{ IPO firms } & \multicolumn{2}{|c|}{ Control group } \\
\hline & Number & $\%$ & Number & $\%$ \\
\hline \multicolumn{5}{|c|}{ Europe } \\
\hline Austria & 5 & 0.6 & 5 & 0.6 \\
\hline Croatia & 5 & 0.6 & 14 & 1.6 \\
\hline Denmark & 11 & 1.3 & 92 & 10.5 \\
\hline Finland & 4 & 0.5 & 88 & 10.0 \\
\hline France & 46 & 5.2 & 7 & 0.8 \\
\hline Germany & 81 & 9.2 & 1 & 0.1 \\
\hline Greece & 8 & 0.9 & 0 & 0 \\
\hline Iceland & 3 & 0.3 & 61 & 6.9 \\
\hline Ireland & 4 & 0.5 & 18 & 2.0 \\
\hline Italy & 28 & 3.2 & 12 & 1.4 \\
\hline Netherland & 9 & 1.0 & 5 & 0.6 \\
\hline Portugal & 3 & 0.3 & 2 & 0.2 \\
\hline Russia & 53 & 6.0 & 4 & 0.5 \\
\hline Spain & 15 & 1.7 & 7 & 0.8 \\
\hline Sweden & 55 & 6.3 & 0 & 0 \\
\hline Switzerland & 20 & 2.3 & 43 & 4.9 \\
\hline $\begin{array}{c}\text { United } \\
\text { Kingdom }\end{array}$ & 48 & 5.5 & 39 & 4.4 \\
\hline \multicolumn{5}{|c|}{ Asia } \\
\hline Malaysia & 68 & 7.7 & 68 & 7.7 \\
\hline Philippines & 17 & 1.9 & 17 & 1.9 \\
\hline Singapore & 52 & 5.9 & 52 & 5.9 \\
\hline Thailand & 25 & 2.8 & 25 & 2.8 \\
\hline Vietnam & 319 & 36.3 & 319 & 36.3 \\
\hline Total & \multicolumn{2}{|c|}{879} & \multicolumn{2}{|c|}{879} \\
\hline
\end{tabular}


Table 3: Descriptive statistics and univariate test (year pre-IPO).

\begin{tabular}{|c|c|c|c|c|c|c|c|c|}
\hline & \multicolumn{3}{|c|}{ Listed firms } & \multicolumn{3}{|c|}{ Unlisted firms } & \multicolumn{2}{|c|}{ Difference tests } \\
\hline & $\mathbf{N}$ & Mean & Median & $\mathbf{N}$ & Mean & Median & $\begin{array}{c}\text { T-stat } \\
\text { (p-value) }\end{array}$ & $\begin{array}{c}\text { Z-stat } \\
\text { (p-value) }\end{array}$ \\
\hline \multicolumn{9}{|c|}{ Panel A: firm characteristic } \\
\hline TA $(\mathrm{mln} \$)$ & 879 & $823,224.5$ & 23,967 & 879 & $2,204,734$ & 43,590 & 0.0000 & 0.0000 \\
\hline Age & 879 & 22.13 & 11 & 879 & 15.25 & 9 & 0.0000 & 0.0000 \\
\hline $\mathrm{CR}(\%)$ & 879 & 41.13 & 40.21 & 879 & 36.77 & 32.73 & 0.0020 & 0.3611 \\
\hline Growth $(\%)$ & 879 & 20.77 & 0.17 & 879 & 8.32 & 0.13 & 0.5444 & 0.0000 \\
\hline $\begin{array}{c}\text { Leverage } \\
(\%)\end{array}$ & 879 & 58.22 & 58.76 & 879 & 72.20 & 67.27 & 0.0000 & 0.0034 \\
\hline \multicolumn{9}{|c|}{ Panel B: firm performance } \\
\hline$R O A(\%)$ & 879 & 5.17 & 6.43 & 879 & 5.73 & 3.63 & 0.6062 & 0.9062 \\
\hline ROA2 (\%) & 879 & 8.72 & 9.94 & 879 & 7.91 & 5.35 & 0.4637 & 0.8654 \\
\hline
\end{tabular}

Table 3, shows the summary characteristics of listed and unlisted firms in the year pre-IPO. Panel A provides means and medians of various characteristics of public companies and private firms, along with associated t-statistics and z-statistics. Panel B provide means and medians of operating performance indicators for public companies and private firms. Means and medians are measured considering both the full sample period (2007-2011). The tests for mean difference are t-test and ztest. 
Table 4: Descriptive statistics and univariate test (years after IPO).

\begin{tabular}{|c|c|c|c|c|c|c|c|}
\hline & \multicolumn{3}{|c|}{ Values } & \multicolumn{4}{|c|}{ Changes } \\
\hline Year (IPO year=1) & $t=1$ & $\mathrm{t}=2$ & $\mathbf{t}=\mathbf{3}$ & $t=4$ & $t=5$ & $1 / 3$ & $1 / 5$ \\
\hline $\begin{array}{c}\text { Roa (lower values } \\
\text { indicate low } \\
\text { profitability) }\end{array}$ & $\begin{array}{c}\text { Mean } \\
\text { (Median) }\end{array}$ & $\begin{array}{c}\text { Mean } \\
\text { (Median) }\end{array}$ & $\begin{array}{c}\text { Mean } \\
\text { (Median) }\end{array}$ & $\begin{array}{c}\text { Mean } \\
\text { (Median) }\end{array}$ & $\begin{array}{c}\text { Mean } \\
\text { (Median) }\end{array}$ & $\begin{array}{c}\text { Mean } \\
\text { (Median) }\end{array}$ & $\begin{array}{c}\text { Mean } \\
\text { (Median) }\end{array}$ \\
\hline (1) IPO firms & $\begin{array}{c}0.063 \\
(0.060)\end{array}$ & $\begin{array}{c}0.049 \\
(0.049)\end{array}$ & $\begin{array}{c}0.026 \\
(0.038)\end{array}$ & $\begin{array}{c}0.026 \\
(0.036)\end{array}$ & $\begin{array}{c}0.020 \\
(0.030)\end{array}$ & $\begin{array}{c}0.336 \\
(-0.333) \\
\end{array}$ & $\begin{array}{c}-1.817 \\
(-0.520)\end{array}$ \\
\hline (2) Control groups & $\begin{array}{c}0.052 \\
(0.039)\end{array}$ & $\begin{array}{c}0.054 \\
(0.039)\end{array}$ & $\begin{array}{c}0.048 \\
(0.032)\end{array}$ & $\begin{array}{c}0.060 \\
(0.042)\end{array}$ & $\begin{array}{c}0.044 \\
(0.038)\end{array}$ & $\begin{array}{c}0.971 \\
(-0.344)\end{array}$ & $\begin{array}{c}4.084 \\
(-0.248)\end{array}$ \\
\hline & Wilcoxon test & $\begin{array}{c}\text { Wilcoxon } \\
\text { test }\end{array}$ & Wilcoxon test & $\begin{array}{c}\text { Wilcoxon } \\
\text { test }\end{array}$ & Wilcoxon test & Wilcoxon test & Wilcoxon test \\
\hline (1) vs. (2) & $-4.446 * * *$ & -1.574 & 0.763 & $2.840 * * *$ & $3.386 * * *$ & $3.225 * * *$ & $5.611 * * *$ \\
\hline & T-stat & T-stat & T-stat & & T-stat & T-stat & T-stat \\
\hline (1) vs. (2) & $-0.011 *$ & $0.019 * *$ & $0.022 * * *$ & $0.034 * * *$ & $0.024 *$ & 0.635 & 5.901 \\
\hline $\begin{array}{c}\text { No. Observations } \\
\text { (1) }\end{array}$ & 879 & 879 & 879 & 879 & 879 & 879 & 879 \\
\hline $\begin{array}{c}\text { No. Observations } \\
(2)\end{array}$ & 879 & 879 & 879 & 879 & 879 & 879 & 879 \\
\hline $\begin{array}{c}\text { Roa2 (lower values } \\
\text { indicate low } \\
\text { profitability) }\end{array}$ & $\begin{array}{c}\text { Mean } \\
\text { (Median) }\end{array}$ & $\begin{array}{c}\text { Mean } \\
\text { (Median) }\end{array}$ & $\begin{array}{c}\text { Mean } \\
\text { (Median) }\end{array}$ & $\begin{array}{c}\text { Mean } \\
\text { (Median) }\end{array}$ & $\begin{array}{c}\text { Mean } \\
\text { (Median) }\end{array}$ & $\begin{array}{c}\text { Mean } \\
\text { (Median) }\end{array}$ & $\begin{array}{c}\text { Mean } \\
\text { (Median) }\end{array}$ \\
\hline (1) IPO firms & $\begin{array}{c}0.095 \\
(0.093) \\
\end{array}$ & $\begin{array}{c}0.066 \\
(0.080) \\
\end{array}$ & $\begin{array}{c}0.055 \\
(0.069) \\
\end{array}$ & $\begin{array}{c}0.053 \\
(0.066) \\
\end{array}$ & $\begin{array}{c}0.055 \\
(0.056) \\
\end{array}$ & $\begin{array}{c}-0.249 \\
(-0.255)\end{array}$ & $\begin{array}{c}-0.240 \\
(-0.390) \\
\end{array}$ \\
\hline (2) Control groups & $\begin{array}{c}0.084 \\
(0.066)\end{array}$ & $\begin{array}{c}0.081 \\
(0.063)\end{array}$ & $\begin{array}{c}0.074 \\
(0.059)\end{array}$ & $\begin{array}{c}0.077 \\
(0.061)\end{array}$ & $\begin{array}{c}0.072 \\
(0.062)\end{array}$ & $\begin{array}{c}-0.244 \\
(-0.139)\end{array}$ & $\begin{array}{c}-0.161 \\
(-0.176)\end{array}$ \\
\hline & Wilcoxon test & $\begin{array}{c}\text { Wilcoxon } \\
\text { test }\end{array}$ & Wilcoxon test & Wilcoxon test & Wilcoxon test & Wilcoxon test & Wilcoxon test \\
\hline (1) vs. (2) & $-5.288 * * *$ & $-2.628 * * *$ & -0.403 & 0.749 & $2.510 * *$ & $2.629 * * *$ & $4.412 * * *$ \\
\hline & T-stat & T-stat & T-stat & T-stat & T-stat & T-stat & T-stat \\
\hline (1) vs. (2) & $-0.011 *$ & $0.015 *$ & $0.019 * * *$ & $0.023 * * *$ & 0.017 & 0.005 & 0.078 \\
\hline $\begin{array}{c}\text { No. Observations } \\
(1)\end{array}$ & 879 & 879 & 879 & 879 & 879 & 879 & 879 \\
\hline
\end{tabular}




\begin{tabular}{|c|c|c|c|c|c|c|c|c|}
\hline $\begin{array}{c}\text { No. Observations } \\
(2)\end{array}$ & 879 & 879 & 879 & 879 & 879 & 879 & 879 \\
\hline \multicolumn{3}{|c|}{ Listed firms } \\
\hline \hline Years (T=2-5)
\end{tabular}

$*, * *$ and $* * *$ indicate statistical significance at $10 \%, 5 \%$ and $1 \%$ levels, respectively.

This table shows univariate tests relative to mean (median) values and mean (median) changes of the indices measuring profitability from the IPO year to four years later of IPO firms and control group. The changes $\left(X_{-}(t+3)-X(t=1)\right) / X(t=1)$; $\left(X_{-}(t-5)-X \_(t=1)\right) / X \_(t=1)$ with $X=$ Roa, Roa2 and $t=1 \ldots 5$, where $t=1$ indicates the IPO year. The test for the equality of distributions is Wilcoxon-Mann-Whitney rank sum test between treated and control groups, while test for mean difference is tstat. Furthermore, we test whether the changes are significantly different from zero (denoted by asterisks) by using a Wilcoxon signed-ranks test for medians and t-stat for mean. 
Table 5: Results from OLS regressions after control for selection bias through a propensity score method.

\begin{tabular}{|c|c|c|}
\hline & (1) & (2) \\
\hline & Roa & Roa2 \\
\hline \multirow[t]{2}{*}{$I P O^{p r e}$} & $0.00998^{* *}$ & $0.0256^{* * *}$ \\
\hline & $(2.27)$ & (5.24) \\
\hline \multirow[t]{2}{*}{$I P O^{\text {post }}$} & $-0.00842^{* * * *}$ & $-0.00619^{* * *}$ \\
\hline & $(-3.76)$ & $(-2.60)$ \\
\hline \multirow[t]{2}{*}{ TA } & -0.000227 & -0.000508 \\
\hline & $(-0.39)$ & $(-0.81)$ \\
\hline \multirow[t]{2}{*}{ Age } & $0.00369^{* * * *}$ & $0.00573^{* * * *}$ \\
\hline & $(3.52)$ & (5.13) \\
\hline State & Yes & Yes \\
\hline Industry & Yes & Yes \\
\hline Year & Yes & Yes \\
\hline Year FE & Yes & Yes \\
\hline$\gamma_{\text {pre- }} \gamma_{\text {post }}$ & $\begin{array}{c}15.08^{* * * *} \\
(0.000)\end{array}$ & $\begin{array}{c}37.20^{* * * *} \\
(0.000)\end{array}$ \\
\hline \multirow[t]{2}{*}{ _cons } & $0.0571^{* * *}$ & $0.0761^{* * * *}$ \\
\hline & (3.34) & (3.94) \\
\hline$N$ & 10284 & 10286 \\
\hline $\operatorname{adj} . R^{2}$ & 0.114 & 0.132 \\
\hline
\end{tabular}

$*$, ** and $* * *$ indicate statistical significance at $10 \%, 5 \%$ and $1 \%$ levels, respectively.

Panel regression analysis of firms' performance of a sample of 879 European and Asian IPOs and 879 private companies is reported considering the casual treatment effect. The dependent variables are Roa (column I), EBIT_TA (column II). IPO-pre is a dummy variable that takes value 1 for firms considered in the one year prior to the IPO and 0 otherwise. IPO-post is a dummy variable that takes value 1 for firms considered in the four years after to the IPO and 0 otherwise. The control variables are: Age, natural logarithm of the firm age. TA, natural logarithm of the total asset. State, Industry and Year dummies are included in the estimates. $\gamma$ pre- $\gamma$ post refers to the Wald test. 
Table 6: Results from Treatment effect model. Panel A reports first-step estimation results of the treatment effect model for European and Asian IPOs.

\begin{tabular}{|c|c|c|}
\hline & (1) & (2) \\
\hline & IPO & IPO \\
\hline \multicolumn{3}{|l|}{ IPO } \\
\hline \multirow[t]{2}{*}{ rend_mkt_avg } & 0.00000276 & 0.00000276 \\
\hline & $(0.06)$ & $(0.06)$ \\
\hline \multirow[t]{2}{*}{ stock_turnover } & $0.00338^{* * *}$ & $0.00338^{* * *}$ \\
\hline & (3.02) & (3.02) \\
\hline \multirow[t]{2}{*}{ credit_gdp } & $-2.44365 \mathrm{e}+09^{* * *}$ & $-2.44365 \mathrm{e}+09^{* * * *}$ \\
\hline & $(-2.85)$ & $(-2.85)$ \\
\hline \multirow[t]{2}{*}{ Age } & 0.0141 & 0.0141 \\
\hline & $(0.36)$ & $(0.36)$ \\
\hline \multirow[t]{2}{*}{ TA } & $-0.0477^{* *}$ & $-0.0477^{* *}$ \\
\hline & $(-2.02)$ & $(-2.02)$ \\
\hline \multirow[t]{2}{*}{ ca_cl } & $0.119^{* * *}$ & $0.119^{* * * *}$ \\
\hline & $(4.71)$ & $(4.71)$ \\
\hline \multirow[t]{2}{*}{ g_sales } & -0.0000978 & -0.0000978 \\
\hline & $(-1.01)$ & $(-1.01)$ \\
\hline State & Yes & Yes \\
\hline Industry & Yes & Yes \\
\hline Year & Yes & Yes \\
\hline \multirow[t]{2}{*}{ _cons } & $2.879^{* * *}$ & $2.879^{* * * *}$ \\
\hline & $(2.98)$ & (2.98) \\
\hline \multirow[t]{3}{*}{$N$} & 1318 & 1318 \\
\hline & (1) & (2) \\
\hline & Roa & Roa2 \\
\hline \multicolumn{3}{|c|}{ Panel B: Second-step approach } \\
\hline \multirow[t]{2}{*}{$I P O$} & $-0.00618^{* * * *}$ & -0.00336 \\
\hline & $(-2.58)$ & $(-1.31)$ \\
\hline \multirow[t]{2}{*}{ TA } & 0.000888 & 0.000103 \\
\hline & $(1.09)$ & $(0.12)$ \\
\hline \multirow[t]{2}{*}{ Age } & $0.00350^{* *}$ & $0.00579^{* * * *}$ \\
\hline & $(2.41)$ & $(3.60)$ \\
\hline State & Yes & Yes \\
\hline Industry & Yes & Yes \\
\hline Year & Yes & Yes \\
\hline \multirow[t]{2}{*}{ Mills } & $-0.0183^{* * *}$ & $-0.0115^{*}$ \\
\hline & $(-2.80)$ & $(-1.71)$ \\
\hline \multirow[t]{2}{*}{ _cons } & 0.0400 & -0.0515 \\
\hline & $(1.63)$ & $(-1.11)$ \\
\hline$N$ & 5184 & 5202 \\
\hline adj. $R^{2}$ & 0.095 & 0.123 \\
\hline
\end{tabular}

$*, * *$ and $* * *$ indicate statistical significance at $10 \%, 5 \%$ and $1 \%$ levels, respectively. 
In this step, we estimate the probability of going public based on average of return of domestic market index (rend_mkt_avg), stock traded of domestic shares (stock_turnover), domestic credit provided by financial sector in percentage of GDP (credit_gdp), firm's logarithm of age (Age), firm's logarithm of size (TA), the ratio of current assets and current liabilities (ca_cl) and growth in sales (g_sales) from a probit model. State, Industry and Year dummies are included in the estimates. The coefficients on the control variables are reported. $\mathrm{N}$ is the number of observations. Panel B reports second-step estimation results of the treatment effect model for European and Asian IPOs. In this step we estimate inverse Mills ratio (Mills) to adjust for selection bias. The dependent variable is the measures of firms' performance: the return on asset (Roa), and the ebit divided by total asset (Roa2). IPO is set to 1 if the firm has launched an IPO and 0 otherwise. The control variables include firm's logarithm of age (Age) and firm's logarithm of size (TA). State, Industry and Year dummies are included in the estimates. The coefficients on the control variables are reported. $\mathrm{N}$ is the number of observations.

Table 7: Results from difference-in-differences combined with propensity score matching.

\begin{tabular}{|c|c|c|}
\hline & (1) & (2) \\
\hline & Roa & Roa2 \\
\hline \multicolumn{3}{|c|}{ Pre-treatment } \\
\hline (1) Matched Private Firms & 0.051 & 0.074 \\
\hline (2) Matched IPO Firms & 0.070 & 0.105 \\
\hline Diff (1)-(2) & $0.019 * * *$ & $0.031 * * *$ \\
\hline No. Observations (1) & 868 & 869 \\
\hline No. Observations (2) & 848 & 844 \\
\hline \multicolumn{3}{|c|}{ Post-treatment } \\
\hline (1) Matched Private Firms & 0.050 & 0.078 \\
\hline (2) Matched IPO Firms & 0.043 & 0.072 \\
\hline $\operatorname{Diff}(1)-(2)$ & $-0.007 * *$ & -0.006 \\
\hline No. Observations (1) & 4280 & 4295 \\
\hline No. Observations (2) & 4294 & 4287 \\
\hline Diff-in-Diff & $-0.026^{* * *}$ & $-0.038^{* * *}$ \\
\hline
\end{tabular}

Table 7, reports the impact of IPO on the firms' performance using difference-indifferences method combined with propensity score before and after the treatment. For each IPO firms, we find a similar unlisted firm based on determinants of IPO. Listed firms are matched to the unlisted firms based on the IPO year characteristics. In order to examine the transition, we consider one year pre-IPO (pre-treatment) and four year post-IPO data (post-treatment). Firms in the two groups are matched by the propensity scores of being public from the logit regression based on their age, 
total assets, market index volatility, sales growth rate, state and industry. We consider the year that an IPO firm go public as the fictitious IPO year for its matched private firm. Firms' performance measures are: the return on asset (Roa), and the ebit divided by total asset (Roa2). Diff-in-Diff is the difference of differences in the average firms' performance of the treatment and control groups from the t-test.

Table 8: Results from difference-in-differences specification and fixed effect model in treatment and control groups.

\begin{tabular}{|c|c|c|c|c|}
\hline \multirow[t]{2}{*}{ Variables } & \multicolumn{2}{|c|}{ Roa } & \multicolumn{2}{|c|}{ Roa2 } \\
\hline & (1) & (2) & (3) & (4) \\
\hline & OLS & FE & OLS & FE \\
\hline Time & $-0.0206^{* * *}$ & $-0.0111^{* * * *}$ & $-0.0177^{* * * *}$ & $-0.00767^{*}$ \\
\hline & $(-6.65)$ & $(-2.72)$ & $(-5.09)$ & $(-1.73)$ \\
\hline Treated & $0.0166^{* * *}$ & - & $0.0317^{* * * *}$ & - \\
\hline & $(2.85)$ & - & $(4.99)$ & - \\
\hline DID & $-0.0160^{* * *}$ & $-0.0155^{* * *}$ & $-0.0281^{* * * *}$ & $-0.0288^{* * *}$ \\
\hline & $(-4.12)$ & $(-4.08)$ & $(-6.51)$ & $(-6.82)$ \\
\hline TA & -0.000160 & -0.000382 & -0.000387 & 0.000236 \\
\hline & $(-0.15)$ & $(-0.11)$ & $(-0.34)$ & $(0.07)$ \\
\hline Age & $0.00397^{* *}$ & $-0.0145^{*}$ & $0.00595^{* * *}$ & $-0.0122^{*}$ \\
\hline & $(2.29)$ & $(-2.36)$ & $(3.11)$ & $(-1.95)$ \\
\hline State & $\mathrm{N}$ & $Y$ & $\mathrm{~N}$ & $\mathrm{Y}$ \\
\hline Industry & $\mathrm{N}$ & $\mathrm{Y}$ & $\mathrm{N}$ & $\mathrm{Y}$ \\
\hline Firm FE & $\mathrm{N}$ & $\mathrm{Y}$ & $\mathrm{N}$ & $\mathrm{Y}$ \\
\hline Year FE & $\mathrm{N}$ & $Y$ & $\mathrm{~N}$ & $Y$ \\
\hline _cons & 0.0166 & $0.102^{* * * *}$ & 0.0520 & $0.116^{* * *}$ \\
\hline & $(0.43)$ & $(2.66)$ & $(1.26)$ & $(2.92)$ \\
\hline$N$ & 10284 & 10284 & 10286 & 10286 \\
\hline adj. $R^{2}$ & 0.109 & 0.033 & 0.126 & 0.038 \\
\hline
\end{tabular}

$*$, ** and $* * *$ indicate statistical significance at $10 \%, 5 \%$ and $1 \%$ levels, respectively.

Table 8, reports the results for a difference-in-differences specification and fixed effects model to examine the differences in trends between treated and control firms before and after the IPO dates. Firms' performance measures are: the return on asset (Roa), and the ebit divided by total asset (Roa2). Time is a dummy variable to 
indicate the time when the treatment started. Treated is a dummy variable to identify the group exposed to the treatment. Diff-in-Diff is the difference of differences in the firms' performance of the treatment and control groups from the t-test. The control variables are: Age, natural logarithm of the firm age. TA, natural logarithm of the total asset. State, Industry dummies are included in the estimates. Firm FE and Year FE refer to firm-fixed and year-fixed effect respectively.

Table 9: Results from OLS regressions after control for selection bias through a propensity score method.

\begin{tabular}{|l|c|c|}
\hline & $(\mathbf{1})$ & $\mathbf{( 2 )}$ \\
\hline & $\mathbf{R o a}$ & $\mathbf{R o a} 2$ \\
\hline & $0.0102^{* *}$ & $0.0261^{* * *}$ \\
\hline $\boldsymbol{I P O}^{\text {in }}$ & $(2.31)$ & $(5.34)$ \\
\hline & 0.00522 & $0.0139^{* * *}$ \\
\hline $\boldsymbol{I P O ^ { \text { post } }}$ & $(1.24)$ & $(2.98)$ \\
\hline & $-0.00822^{* * *}$ & $-0.00566^{* * *}$ \\
\hline TA & $(-3.66)$ & $(-2.37)$ \\
\hline & -0.000212 & -0.000468 \\
\hline Age & $(-0.36)$ & $(-0.75)$ \\
\hline & $0.00369^{* * *}$ & $0.00575^{* * *}$ \\
\hline State & $(3.52)$ & $(5.14)$ \\
\hline Industry & Yes & Yes \\
\hline Year & Yes & Yes \\
\hline Year FE & Yes & Yes \\
\hline $\boldsymbol{\gamma}_{\text {pre- }} \boldsymbol{\gamma}_{\text {in }}$ & Yes & Yes \\
\hline $\boldsymbol{\gamma}_{\text {in- }} \boldsymbol{\gamma}_{\text {post }}$ & 0.70 & $3.46^{*}$ \\
\hline cons & $(0.403)$ & $(0.062)$ \\
\hline & $8.65^{* * *}$ & $15.25^{* * *}$ \\
\hline $\boldsymbol{N}$ & $0.003)$ & $(0.000)$ \\
\hline adj. $\boldsymbol{R}^{\mathbf{2}}$ & $(3.32)$ & $0.0750^{* * *}$ \\
\hline
\end{tabular}

$*$, ** and $* * *$ indicate statistical significance at $10 \%, 5 \%$ and $1 \%$ levels, respectively.

Panel regression analysis of firms' performance of a sample of 879 European and Asian IPOs and 879 private companies is reported considering the casual treatment effect. The dependent variables are Roa (column I), and Roa2 (column II). IPO-pre is a dummy variable that takes value 1 for firms considered in the one year prior to the IPO and 0 otherwise. IPO-in is a dummy variable that takes value 1 for firms considered in the IPO's year and 0 otherwise. IPO-post is a dummy variable that 
takes value 1 for firms considered in the four years after to the IPO and 0 otherwise. The control variables are: Age, natural logarithm of the firm age. TA, natural logarithm of the total asset. State, Industry and Year dummies are included in the estimates. $\gamma$ pre- $\gamma$ in and $\gamma$ in- $\gamma$ post refers to the Wald test.

Table 10: Results from OLS regressions after control for selection bias through a propensity score method.

\begin{tabular}{|c|c|c|}
\hline & (1) & (2) \\
\hline & Roa & Roa2 \\
\hline \multirow[t]{2}{*}{$I \boldsymbol{O}^{\text {pre }}$} & $0.0102^{* *}$ & $0.0261^{* * * *}$ \\
\hline & $(2.31)$ & $(5.34)$ \\
\hline \multirow[t]{2}{*}{$I P O^{\text {in }}$} & 0.00522 & $0.0139^{* * *}$ \\
\hline & $(1.24)$ & $(2.98)$ \\
\hline \multirow[t]{2}{*}{$I P O^{\text {post } 1}$} & -0.000944 & 0.00386 \\
\hline & $(-0.24)$ & $(0.87)$ \\
\hline \multirow[t]{2}{*}{$I P O^{p o s t 2}$} & $-0.00859^{* *}$ & -0.00603 \\
\hline & $(-2.13)$ & $(-1.46)$ \\
\hline \multirow{2}{*}{$I P O^{\text {post3 }}$} & $-0.0113^{* * *}$ & $-0.00809^{*}$ \\
\hline & $(-2.65)$ & $(-1.83)$ \\
\hline \multirow{2}{*}{ IPO $^{\text {post } 4}$} & $-0.0121^{* * *}$ & $-0.0124^{* * *}$ \\
\hline & $(-2.83)$ & $(-2.72)$ \\
\hline \multirow[t]{2}{*}{ TA } & -0.000218 & -0.000477 \\
\hline & $(-0.37)$ & $(-0.76)$ \\
\hline \multirow[t]{2}{*}{ Age } & $0.00370^{* * *}$ & $0.00576^{* * * *}$ \\
\hline & $(3.53)$ & $(5.15)$ \\
\hline State & Yes & Yes \\
\hline Industry & Yes & Yes \\
\hline Year & Yes & Yes \\
\hline Year FE & Yes & Yes \\
\hline$\gamma_{\text {pre- }} \gamma_{\text {in }}$ & $\begin{array}{c}0.70 \\
(0.404) \\
\end{array}$ & $\begin{array}{c}3.46^{*} \\
(0.062) \\
\end{array}$ \\
\hline$\gamma_{\text {in- }} \gamma_{\text {post1 }}$ & $\begin{array}{c}1.19 \\
(0.275)\end{array}$ & $\begin{array}{c}2.58 \\
(0.108)\end{array}$ \\
\hline$\gamma_{\text {in- }} \gamma_{\text {post2 }}$ & $\begin{array}{c}5.94^{* *} \\
(0.014)\end{array}$ & $\begin{array}{l}10.89^{* * * *} \\
(0.001)\end{array}$ \\
\hline$\gamma_{\text {in- }} \gamma_{\text {post3 }}$ & $\begin{array}{l}8.01^{* * * *} \\
(0.004)\end{array}$ & $\begin{array}{l}12.38^{* * * *} \\
(0.000)\end{array}$ \\
\hline$\gamma_{\text {in- }} \gamma_{\text {post4 }}$ & $\begin{array}{l}8.83^{\text {*** }} \\
(0.003)\end{array}$ & $\begin{array}{l}17.31^{* * * *} \\
(0.000)\end{array}$ \\
\hline \multirow[t]{2}{*}{ cons } & $0.0567^{* * * *}$ & $0.0748^{* * *}$ \\
\hline & $(3.32)$ & $(3.90)$ \\
\hline$N$ & 10284 & 10286 \\
\hline$R^{2}$ & 0.124 & 0.142 \\
\hline adj. $R^{2}$ & 0.114 & 0.133 \\
\hline
\end{tabular}

$*, * *$ and $* * *$ indicate statistical significance at $10 \%, 5 \%$ and $1 \%$ levels, respectively. 
Panel regression analysis of firms' performance of a sample of 879 European and Asian IPOs and 879 private companies is reported considering the casual treatment effect. The dependent variables are Roa (column I), and Roa2 (column II). IPO-pre is a dummy variable that takes value 1 for firms considered in the one year prior to the IPO and 0 otherwise. IPO-in is a dummy variable that takes value 1 for firms considered in the IPO's year and 0 otherwise. IPO-post 1 is a dummy variable that takes value 1 for firms considered to the first year after the IPO and 0 otherwise. IPO-post 2 is a dummy variable that takes value 1 for firms considered to the second year after the IPO and 0 otherwise. IPO-post 3 is a dummy variable that takes value 1 for firms considered to the third year after the IPO and 0 otherwise. IPO-post 4 is a dummy variable that takes value 1 for firms considered to the fourth year after the IPO and 0 otherwise. The control variables are: Age, natural logarithm of the firm age. TA, natural logarithm of the total asset. State, Industry and Year dummies are included in the estimates. $\gamma$ pre- $\gamma$ in and $\gamma$ in- $\gamma$ post refers to the Wald test.
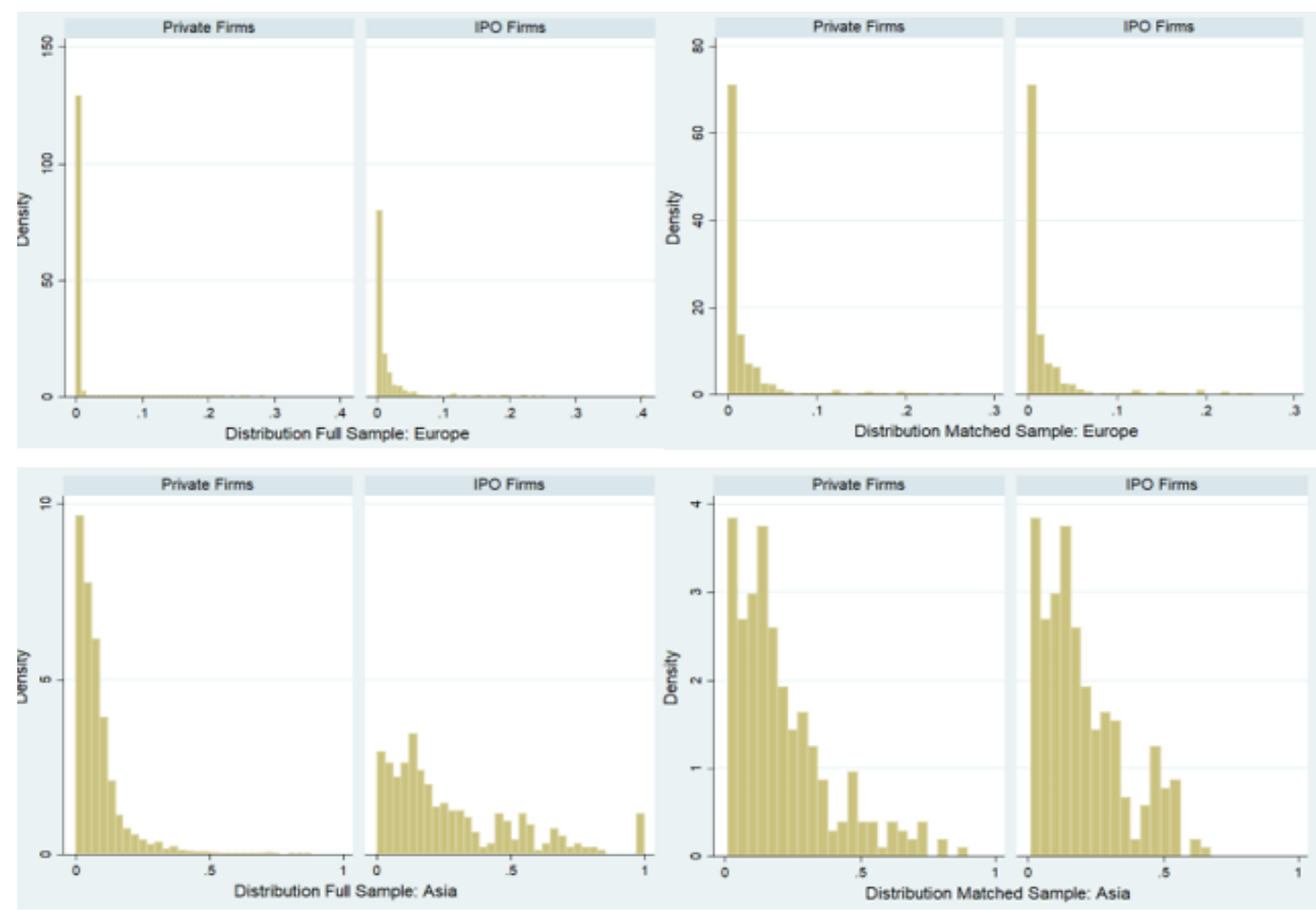

Figure 1: Sample distribution of IPO and private firms before and after propensity score matching.

These figures report the sample distribution of European and Asian IPO and private firms before and after the implementation of propensity score matching. 

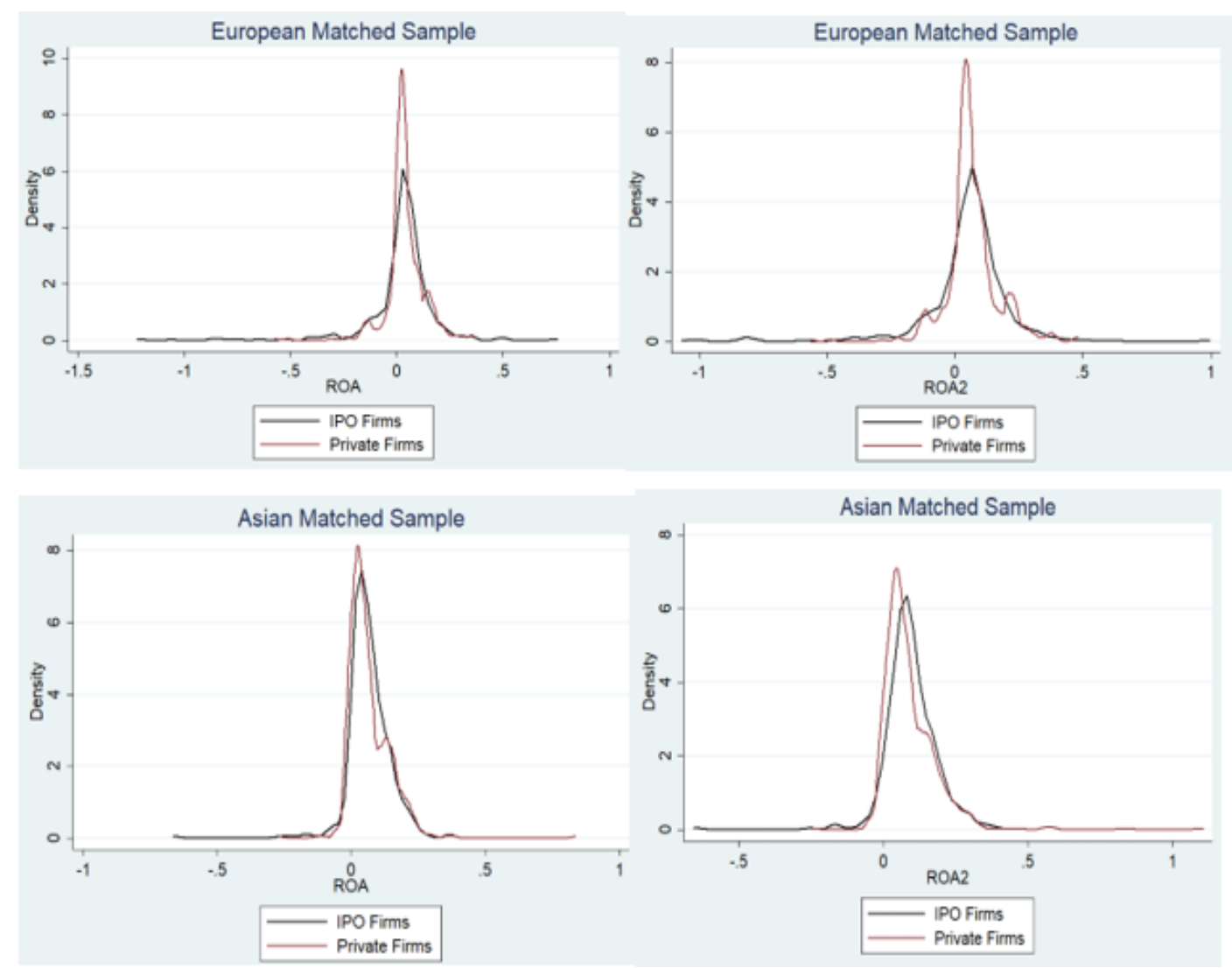

Figure 2: Profitability distribution of IPO and private firms.

These figures report the profitability (ROA and ROA2) distribution of European and Asian IPO and private firms after the implementation of propensity score matching. 


\section{References}

[1] Acharya, V., and Xu, Z. (2017). Financial dependence and innovation: The case of public versus private firms. Journal of Financial Economics, Vol. 124, Issue 2, pp. 223 - 243.

[2] Alhadab, M., Clacher, I., and Keasey, K. (2016). A comparative analysis of real and accrual earnings management around initial public offerings under different regulatory environments. Journal of Business Finance \& Accounting, Vol. 43, Issue 7-8, pp. 849 - 871.

[3] Allen, F., and Faulhaber, G.R. (1989). Signaling by underpricing in the IPO market. Journal of Financial Economics, Vol. 23, 2, pp. 303 - 324.

[4] Anderson, R.C., and Reeb, D.M. (2003). Founding-Family Ownership and Firm Performance: Evidence from the S\&P 500. The Journal of Finance, Vol. 58, Issue 3, pp. 1301 - 1328.

[5] Andrade, G., and Kaplan, S.N. (1998). How costly is financial (not economic) distress? Evidence from highly levered transactions that became distressed. Journal of Finance, Vol. 53, Issue 5, pp. 1443 - 1493.

[6] Asker, J., Farre-Mensa, J., and Ljungqvist, A. (2016). Corporate Investment and Stock Market Listing: A Puzzle?. Review of Financial Studies, Vol. 28, Issue 2, pp. 342 - 390.

[7] Bancel, F., and Mittoo, U.R. (2009). Why do European firms go public?, European Financial Management, Vol. 15, Issue 4, pp. 844 - 84.

[8] Berle, A., and Means, G. (1932). The Modern Corporation and Private Property. Macmillan, New York.

[9] Bernstein, S. (2015). Does Going Public Affect Innovation?. The Journal of Finance, Vol. 70, Issue 4, pp. 1365 - 1403.

[10] Bhide, A. (1993). The hidden cost of stock market liquidity. Journal of Financial Economics, Vol. 34, pp. 34 - 51.

[11] Blundell, R., and Dias, M.C. (2000). Evaluation methods for non-experimental data. Fiscal Studies, Vol. 21, Issue 4, pp. 427 - 468.

[12] Bolton, P., and Von Thadden, E. (1998). Blocks, liquidity, and corporate control. Journal of Finance, Vol. 53, Issue 1, pp. 1 - 26.

[13] Bolton, P., Scheinkman, J., and Xiong, W. (2006). Executive compensation and short-termist behaviour in speculative markets. Review of Economic Studies, 73, Issue 3, pp. 577 - 610.

[14] Booth, J.R., and Chua, L. (1996). Ownership dispersion, costly information, and IPO underpricing. Journal of Financial Economics, Vol. 41, Issue 2, pp. $151-310$.

[15] Brav, A., Jiang, W., Ma, S., and Tian, X. (2018). How Does Hedge Fund Activism Reshape Corporate Innovation? Journal of Financial Economics, Vol. 130, Issue 2, pp. 237 - 264.

[16] Brav, O. (2009). Access to Capital, Capital Structure, and the Funding of the Firm. The Journal of Finance, Vol. 64, Issue 1, pp. 263 - 308. 
[17] Campbell, T.S. (1979). Optimal investment financing decisions and the value of confidentiality. Journal of Financial and Quantitative Analysis, Vol. 14, Issue 5, pp. 913 - 924.

[18] Chen, C., Shi, H., and Xu, H. (2013). Underwriter reputation, issuer ownership, and pre-IPO earnings management: Evidence from China. Financial Management, Vol. 42, Issue 3, pp. 647 - 677.

[19] Chemmanur, T.J., and Fulghieri, P. (1999). A theory of the Going-Public Decision. Review of Financial Studies, Vol. 12, Issue 2, pp. 249 - 279.

[20] Chemmanur, T.J., He, S., and Nandy, D.K. (2010). The Going-Public Decision and the Product Market. Review of Financial Studies, Vol. 23, Issue 5, pp. $1855-1908$.

[21] De Angelo, H., and De Angelo, L. (1990). Dividend Policy and Financial Distress: An Empirical Investigation of Troubled NYSE Firms. The Journal of Finance, Vol. 45, Issue 5, pp. 1415 - 1431.

[22] European Commission (2008). Internal Market, Industry, Entrepreneurship and SMEs.

[23] Gennaioli, N., Martin, A., and Rossi, S. (2014). Sovereign default, domestic banks, and financial institutions. The Journal of Finance, Vol. 69, Issue 2, pp. $819-866$.

[24] Gilje, E.P., and Taillard, J.P. (2016). Do private firms invest differently than public firms? Taking cues from the natural gas industry. The Journal of Finance, Vol. 71, Issue 4, pp. 1733 - 1778.

[25] Hellmann, T. (2006). IPOs, acquisitions, and the use of convertible securities in venture capital. Journal of Financial Economics, Vol. 81, Issue 3, pp. 649 679.

[26] Helwege, J., and Liang, N. (1996). Initial public offerings in hot and cold markets. Discussion Paper no. 96/34, Board of Governors of the Federal Reserve System, Washington, DC.

[27] Holmström, B., and Tirole, J. (1993). Market Liquidity and Performance Monitoring. Journal of Political Economy, Vol. 101, Issue 4, pp. 678 - 709.

[28] Hope, O.K., Thomas, W.B., and Vyas, D. (2013). Financial reporting quality of US private and public firms. The Accounting Review, Vol. 88, Issue 5, pp. $1715-1742$.

[29] Huynh, K., Paligorova, T., and Petrunia, R. (2018). Debt financing in private and public firms. Annals of Finance, Vol. 14, pp. 1 - 23.

[30] Jain, B.A., Kini, O. (1994). The Post-Issue Operating Performance of IPO Firms. The Journal of Finance, Vol. 49, Issue 5, pp. 1699 - 1726.

[31] Jensen, M., and Meckling, W.H. (1976). Theory of the firm: Managerial behaviour, agency costs and ownership structure. Journal of Financial Economics, Vol. 3, Issue 4, pp. 305 - 360.

[32] Kim, K., Kitsabunnarat, P., and Nofsinger, J.R. (2004). Ownership and operating performance in an emerging market: Evidence from Thai IPO firms. Journal of Corporate Finance, Vol. 10, Issue 3, pp. 355 - 381. 
[33] Kouwenberg, R., and Thontirawong, P. (2016). Group affiliation and earnings management of Asian IPO issuers. Review of Quantitative Finance and Accounting, Vol. 47, Issue 4, pp. 897 - 917.

[34] La Porta, R., Lopez-De-Silanes, F., Shleifer, A., and Vishny, R. (2000). Agency problems and dividend policies around the world. Journal of Finance, Vol. 55, Issue 1, pp. 1 - 33.

[35] Latham, S., and Braun, M.R. (2010). To IPO or not to IPO: risk, uncertainty and the decision to go public. British Journal of Management, Vol. 21, Issue 3, pp. $666-683$.

[36] Lee, P.M., and Wahal, S. (2004). Grandstanding, certification and the underpricing of venture capital backed IPOs. Journal of Financial Economics, Vol. 73, Issue 2, pp. 375 - 407.

[37] Leland, H.E., and Pyle, D.H. (1977). Informational Asymmetries, Financial Structure, and Financial Intermediation. The Journal of Finance, Vol. 32, Issue 2, pp. 371 - 387.

[38] Ljungqvist, A.P., and Wilhelm, W.J. (2001). IPO Allocations: Discriminatory or Discretionary?. Journal of Financial Economics, Vol. 65, pp. 167 - 201.

[39] Lo, K., Ramos, F., and Rogo, R. (2014). Earnings Management and Annual Report Readability. Journal of Accounting and Economics, Vol. 63, Issue 1, pp. 1 - 25.

[40] Loughran, T., and Ritter, J., (1995). The new issues puzzle. Journal of Finance. Vol. 50, Issue 1, pp. 23 - 51.

[41] Maksimovic, V., and Pichler, P. (2001). Technological Innovation and Initial Public Offerings. Review of Financial Studies, Vol. 14, Issue 2, pp. 459 - 494.

[42] Martinez, J.I., Stohr, B.S., and Quiroga, B.F. (2007). Family Ownership and Firm Performance: Evidence from Public Companies in Chile. Family Business Review, Vol. 20, Issue 2, pp. 83 - 94.

[43] Mazzola, P., and Marchisio, G., (2002). The Role of Going Public in Family Businesses' Long-Lasting Growth: A Study of Italian IPOs. Family Business Review, Vol. 15, Issue 2, pp. 133 - 148.

[44] Megginson, W.L., Meles A., Sampagnaro G., and Verdoliva V. (2016). Financial distress risk in initial public offerings: How much do venture capitalists matter? Journal of Corporate Finance, Vol. 59, pp. 10 - 30.

[45] Michaely, R., and Roberts, M.R. (2012). Corporate Dividend Policies: Lessons from Private Firms. Review of Financial Studies, Vol. 25, Issue 3, pp. 711 746.

[46] Mikkelson, W., Partch, M.M., and Shah, K. (1997). Ownership and operating performance of companies that go public. Journal of Financial Economics, Vol. 44, Issue 3, pp. 281 - 307.

[47] Mortal, S., and Reisel, N. (2013). Capital Allocation by Public and Private Firms. Journal of Financial and Quantitative Analysis, Vol. 48, Issue 1, pp. 77 $-103$.

[48] Pacter, P. (2007). Should U.S. private companies use IFRS for SMEs? Available on-line at www.financialexecutivemag.com. 
[49] Pagano, M., Panetta, F., and Zingales, L. (1998). Why Do Companies Go Public?. The Journal of Finance, Vol. 53, 1, pp. 27 - 64.

[50] Pagano, M., and Röell, A. (1998). The choice of stock ownership structure: Agency costs, monitoring, and the decision to go public. Quarterly Journal of Economics, Vol. 113, Issue 1, pp. 187 - 225.

[51] Pástor, L., Taylor, L.A., and Veronesi, P. (2009). Entrepreneurial Learning, the IPO Decision, and the Post-IPO Drop in Firm Profitability. The Review of Financial Studies, Vol. 22, Issue 8, pp. 3005 - 3046.

[52] Rajan, R., and Servaes, H. (1997). Analyst following of initial public offerings. The Journal of Finance, Vol. 52, Issue 2, pp. 507 - 529.

[53] Ritter, J.R. (1984). The "Hot Issue" Market of 1980. The Journal of Business, Vol. 57, Issue 2, pp. 215 - 240.

[54] Ritter, J.R. (1991). The long-run performance of initial public offerings. The Journal of Finance, Vol. 46, Issue 1, pp. 3 - 27.

[55] Ritter, J., and Welch, I., 2002. A review of IPO activity, pricing, and allocations. Journal of Finance, 57, Issue 4, pp. 1795 - 1828.

[56] Rosenbaum, P.R., and Rubin, D.B. (1983). The Central Role of the Propensity Score in Observational Studies for Causal Effects. Biometrika, Vol. 70, Issue 1 , pp. $41-55$.

[57] Rydqvist, K., and Hoghölm, K. (1995). Going public in the 1980s: Evidence from Sweden. European Financial Management, Vol. 1, Issue 3, pp. 287 - 315.

[58] Saunders, A., and Steffen, S. (2011). The Costs of Being Private: Evidence from the Loan Market. The Review of Financial Studies, Vol. 24, Issue 12, pp. $4091-4122$.

[59] Schepens, G. (2016). Taxes and bank capital structure. Journal of Financial Economics, Vol. 120, Issue 3, pp. 585 - 600.

[60] Stein, J., (1989). Efficient capital markets, inefficient firms: A model of myopic corporate behaviour. Quarterly Journal of Economics, Vol. 104, Issue 4, pp. $655-669$.

[61] Stoughton, N.M., and Zechner, J. (1998). IPO-mechanisms, monitoring and ownership structure. Journal of Financial Economics, Vol. 49, Issue 1, pp. 45 $-77$.

[62] Teoh, S.H., Welch, I. and Wong, T.J. (1998). Earnings Management and the Long-Run Market Performance of Initial Public Offerings. The Journal of Finance, Vol. 53, Issue 6, pp. 1935 - 1974.

[63] Wang, C. (2005). Ownership and operating performance of Chinese IPOs. Journal of Banking \& Finance, Vol. 29, Issue 7, pp. 1835 - 1856.

[64] Yosha, O. (1995). Information Disclosure Costs and the Choice of Financing Source. Journal of Financial Intermediation, Vol. 4, Issue 1, pp. 3 - 20. 